\title{
Stomatal Conductance and Chlorophyll Characteristics and Their Relationship with Yield of Some Cocoa Clones Under Tectona grandis, Leucaena sp., and Cassia surattensis
}

\author{
Fakhrusy Zakariyya ${ }^{1 *}$ and A. Adi Prawoto ${ }^{1)}$ \\ ${ }^{1}$ Indonesian Coffee and Cocoa Research Institute, Jl. PB. Sudirman 90, Jember Indonesia \\ ${ }^{*}$ Corresponding author: fakhrusy.zakariyya@gmail.com
}

\begin{abstract}
An optimum physiological condition will support high yield and quality of cocoa production. The research was aimed to study the effects of stomatal conductance and chlorophyll content related to cocoa production under three shade regimes. This research was conducted in Kaliwining Experimental Station, elevation of $45 \mathrm{~m}$ above sea level with D climate type based on Schmidt \& Fergusson. Cocoa trees which were planted in 1994 at a spacing of 3 X 3 m were used in the study planted by using split plot design. The shade tree species were teak (Tectona grandis), krete (Cassia surattensis), and lamtoro (Leucaena sp.) as the main plots, and cocoa clones of Sulawesi 01, Sulawesi 02, KKM 22 and KW 165 as sub plots. This study showed that there was interaction between cocoa clone and shade species for stomatal conductance where stomatal diffusive resistance of KKM 22 was the best under Leucaena sp. and Cassia surattensis with the values of 1.38 and $1.34 \mathrm{s.cm}{ }^{-1}$, respectively. The highest chlorophyll content, stomatal index and transpiration values was under Leucaena sp. shade. There was positive correlation between chlorophyll content and transpiration with pod yield of cocoa. The highest yield and the lowest bean count were obtained on Sulawesi 01 clone under Leucaena sp. shade.
\end{abstract}

Keywords: stomatal conductance, transpiration, diffusive resistance, shades trees, clones, pod yield

\section{INTRODUCTION}

During many years, cocoa has been regarded as a favored export commodity in Indonesia. Cocoa farming involves about 1.6 million farmers for the industry. Cocoa production in Indonesia has reached 833,310 tons/year which occupies the $3^{\text {rd }}$ largest producer after Ghana and Ivory Coast (Ditjenbun, 2012).

Several factors which affecting production are climatic factors and crop management systems such as shade, pruning, fertilizing and genetic properties (Cannell, 1985; Susilo, 2015). Considering that cocoa is a $\mathrm{C} 3$ plant which is shade loving tree, then it needs suitable micro-climatic conditions for optimum growth. Meanwhile, studies have shown that shade management in cocoa plantation can mitigate the effects of extreme temperature and precipitation, there by reducing the ecological and economic vulnerability of farmer (Da Matta et al., 2007).

Young cocoa plants require light intensity around $25-60 \%$ of whole light intensity for their growth (Abdoellah \& Soedarsono, 1996) while the intensity of 50-70\% reported that provided the highest production of mature cocoa (Prawoto, 2012). Previous research has studied that solar energy efficiency conversion 
under that lamtoro (Leucaena sp.) shade was $59.8 \%$ which was higher than under Cassia sp. and Tectona grandis shades for several clones of cocoa (Regazzoni et al., 2015). Meanwhile, the shade was reported to have an important role in providing optimum conditions in some cocoa plant physiological conditions, primarily leaf area index (LAI), chlorophyll and stomatal density, but some other physiological characteristics were needed to be studied (Regazzoni et al., 2014).

Photosynthesis is a key condition in the establishment of the plant assimilates. The factors that determine the photosynthesis are the availability of $\mathrm{CO}_{2}$ and $\mathrm{H}_{2} \mathrm{O}$ while the synthesis of carbohydrates is influenced by light and chlorophyll. $\mathrm{CO}_{2}$ and $\mathrm{H}_{2} \mathrm{O}$ distribution is determined by stomatal conductance. Stomatal diffusion resistance is directly related to the process of photosynthesis. The process of photosynthesis requires $\mathrm{CO}_{2}$, one of the substrate in the process of photosynthesis, which is obtained from the air, taken by leaves up by diffusion through the stomata, subsequently in the process of uptake, stomata diffusion resistance has very important role (Salisbury \& Ross, 1975). Chlorophyll in leaves is as a pigment that absorbs sunlight for photosynthesis process, especially in light reaction processes (Prawoto, 2015).

Transpiration is an important dynamic physiological activity and plays a role in regulatory mechanism and adaptation to internal and external conditions of its performance, mainly associated with the control of fluids (cells tissue turgidity), absorption and transport of water, mineral, nutrient and tissue temperature (Lakitan, 2013).

An optimum physiological condition will support the production and the quality of crop production. Studies have shown that shade trees assist in maintaining coffee yields in the long term by reducing periodic over-bearing and subsequent die-back of coffee branches (DaMatta et al., 2007). However, shade may positively affect bean size and composition as well as beverage quality by delaying and synchronizing berry flesh ripening (Muschler, 2001). The study of physiology and its effect on production and quality of cocoa beans in various shade conditions need further study. This aim of this research was to investigate the effects of stomatal conductance and chlorophyll content related to cocoa production under three shade species.

\section{MATERIALS AND METHODS}

Field experimental was conducted in Kaliwining Experimental Station, Indonesian Coffee and Cocoa Research Institute, Jember, Indonesia at an elevation of $48 \mathrm{~m}$ above sea level. The soils are classified as low humic loamy clay with D climate type based on Schmidt \& Fergusson classification. The layout was split plot in randomised complete block design, with three replications. The study was carried out during April 2014 - May 2015.

The cocoa trees, which were planted in 1994 of plant material were used in the study. The trees were planted at a spacing of $3 \mathrm{~m} \times 3 \mathrm{~m}$. The shades were teak (Tectona grandis), krete (Cassia surattensis), and lamtoro (Leucaena sp.) as a main plots. The cocoa clones were Sulawesi 01, Sulawesi 02, KKM 22 and KW 165 as sub plots.

Temperature and relative humidity under the shade trees were measured using thermohygrometer, recorded at $10.00 \mathrm{AM}$. Ground coverage used fish eye capture method and anlalyzed by using Software Hemiview Canopy Analysis Delta-T.

Simultaneous records of photosynthetically active radiation (PAR), leaf temperature, stomatal diffusive resistance and leaf 
transpiration were taken using a steady state porometer (LI-1600, Licor incorporation, USA). For this purpose, the equipment was tagged on leaves of each plant (the youngest or second youngest fully expanded, fully hardened leaf in each case) which are reported to be the most physiologically active (Daymond et al., 2011). For the gas exchange measurements, leaf chamber temperatures was $29.5-30.1^{\circ} \mathrm{C}$.

Stomatal index was observed through slathered stomata by using nail polish. Polish applied to the abaxial leaf and observed under a microscope. Number of stomata and leaf epidermis were observed to determine the stomatal index. Stomatal index obtained from:

Stomatal Index $=$

$\frac{\text { The number of stomata }}{\text { (number of stomata }+ \text { number of epidermis) }} \times 100 \%$

Chlorophyll content was measured by using SPAD-502 Chlorophyll meter Minolta. The value of SPAD (unit) was converted to chlorophyll content according to the equation of Markwell et al. (1995). Chlorophyll content $=10\left(\mathrm{M}^{0.256}\right) \mu \mathrm{mol} \mathrm{m}{ }^{-2}$ where $\mathrm{M}$ is measurement result.

For this observation, in each plot 10 plants were determined using systematically random sampling. On April and September, small pods number (length $2-10 \mathrm{~cm}$ ), medium pods (length $11-15 \mathrm{~cm}$ ), large pods (length $>15 \mathrm{~cm}$ ) was observed. The expected yield was calculated by using the opportunities to be harvested as followed $20 \%$ of small; $75 \%$ of medium; and $95 \%$ of large pods (Prawoto, 2014).

Data were analyzed using analysis of variance, if there is a significant difference then it is continued with Duncan test at $5 \%$ level. Regression analysis was also conducted to determine the relationship among of parameters.

\section{RESULTS AND DISCUSSION}

According to Table 1. the temperature in three shade regines during the rainy season showed almost the same value that was 34$35^{\circ} \mathrm{C}$, but the moisture in the shade on teak was higher due to the canopy was denser than others. While the optimum shade on lamtoro, the temperature and humidity was $38^{\circ} \mathrm{C}$ and $50 \%$ in the dry season and 35 and $71 \%$ in the wet season, respectively. The optimum temperature for a cocoa plantation is $22.4-30.4^{\circ} \mathrm{C}$ to support photosyntesis processes (Prawoto, 2015).

Ground coverage is a description about the coverage of incoming light to the ground due to the obstruction of shade canopy. Based on Table 1, the ground coverage of Leucana sp. was $38 \pm 6.8 \%$ (62\% of light illumination), Cassia suratenesis was $49.6 \pm$ $8.2 \%$ (51.4\% of light illumination), and teak was $57 \pm 6.8 \%$ ( $43 \%$ light illumination). Regazzoni et al. (2014) reported that increasing solar energy efficiency was followed by an increasing the percentage of shading, where Leucaena sp. (60\% shading) absorbed solar energy lower than Tectona grandis and Cassia surattensis.

Stomatal diffusion resistance is resistance to the movement of gas from high concentration to low concentration through stomata. Stomatal resistance inhibits gases which will enter through the stomata (Salisbury \& Ross, 1975). Interaction between shade and clones showed some significant differences in the value of stomatal diffusion resistance. Leucaena sp. shade showed no significant difference in the values of the four clones, as well as clones under the shade Cassia surattenensis. However, KKM 22 clone in the shade of Tectona grandis showed significant difference under shade Leucaena sp. and Cassia surattensis which amounted to $2.28 \mathrm{~s} / \mathrm{cm}$. However, the value 
of stomatal diffusion resistance at KKM 22 clone in Cassia surattensis shade was the lowest.

The higher the value of stomatal resistance, the larger the gas (included $\mathrm{CO}_{2}$ ) diffusion barrier that enters into leaves will be, so that photosynthesis will be smaller. The higher the intensity of incoming light, the lower the stomatal diffusion resistance. It can be shown by the negative value of the linear regression $\left(R^{2}=-0.11\right.$, data is not presented $)$ between stomatal diffusion resistance and the percentage of shading.

According to Drake et al. (2006), the stomatal characters affect the mechanism of gas exchange in the plant. Stomatal response with respect to the time was an important factor to determine the gas exchange on the leaf, so it can be seen the optimum environmental conditions. However, rate of the response of stomata will also affect the photoshyntesis and transpiration process, so it can be used to make improvements to the transpiration efficiency.

The single factor of shade species and clones provides significant different values. The highest transpiration was given by clone Sulawesi 01 that was not significantly different from KKM 22 and Sulawesi 02 clones, but significantly different from the KW 165 clone. In contrast to the treatment of shade species, the higher the intensity of the radiation, the higher the transpiration will be. At this point, the transpiration under Leucaena sp. shading (60\% light intensity) was $2.46 \mu \mathrm{g} . \mathrm{cm}^{-2} . \mathrm{s}^{-1}$ that was the higest than Cassia surattensis (50\% shading) and Tectona grandis were $2.25 \mu \mathrm{g} . \mathrm{cm}^{-2} \cdot \mathrm{s}^{-1}$ and $2.11 \mu \mathrm{g} . \mathrm{cm}^{-2} \cdot \mathrm{s}^{-1}$, respectively (Table 3 ).

Mayolie \& Gitau (2012) study showed that the increasing of stomatal conductance $\left(\mathrm{s} . \mathrm{cm}^{-1}\right)$ (reverse of diffusive resistance

Table 1. Microclimatic conditions recorded under different shade species during dry and wet seasons

\begin{tabular}{|c|c|c|c|c|c|}
\hline \multirow{2}{*}{ Shade trees } & \multicolumn{2}{|c|}{ Rainy season } & \multicolumn{2}{|l|}{ Dry season } & \multirow{2}{*}{ Ground coverage, $\%$} \\
\hline & Temperature, ${ }^{\mathrm{O}} \mathrm{C}$ & $\mathrm{RH}, \%$ & Temperature, ${ }^{\circ} \mathrm{C}$ & $\mathrm{RH}, \%$ & \\
\hline Tectona grandis & 34 & 75 & 39 & 50 & $57 \pm 6.8$ \\
\hline Leucaena sp. & 35 & 71 & 38 & 50 & $38 \pm 6.8$ \\
\hline Cassia surattensis & 34 & 72 & 38 & 49 & $49.6 \pm 8.2$ \\
\hline
\end{tabular}

Table 2. Effects of shade tree species and cocoa clones on stomatal diffusion resistance

\begin{tabular}{lccc}
\hline Stomatal diffusion resistance $\left({\left.\mathrm{s} . \mathrm{cm}^{-1}\right)}^{-}\right.$ & Leucaena sp. & Tectona grandis & Cassia surattensis \\
\hline Sulawesi 01 & $1.44 \mathrm{a}$ & $1.42 \mathrm{a}$ & $1.79 \mathrm{ab}$ \\
Sulawesi 02 & $1.89 \mathrm{ab}$ & $1.82 \mathrm{ab}$ & $1.86 \mathrm{ab}$ \\
KKM 22 & $1.38 \mathrm{a}$ & $2.28 \mathrm{~b}$ & $1.34 \mathrm{a}$ \\
$\mathrm{KW} 165$ & $1.48 \mathrm{a}$ & $1.54 \mathrm{a}$ & $1.71 \mathrm{ab}$ \\
\hline Note: $\quad$ number within the same column follow by the same letter are not significantly different at $5 \%$ level according to &
\end{tabular}

Table 3. Effects of shade tree species and cocoa clones on transpiration

\begin{tabular}{|c|c|c|c|}
\hline Shade trees & Transpiration, $\mu$ gram. $\mathrm{cm}^{-2} \cdot \mathrm{s}^{-1}$ & Clones & Transpiration, $\mu$ gram. $\mathrm{cm}^{-2} \cdot \mathrm{s}^{-1}$ \\
\hline Leucaena sp. & $2.46 \mathrm{a}$ & Sulawesi 01 & $2.48 \mathrm{a}$ \\
\hline Cassia surattensis & $2.33 \mathrm{ab}$ & Sulawesi 02 & $2.21 \mathrm{ab}$ \\
\hline \multirow[t]{2}{*}{ Tectona grandis } & $2.30 \mathrm{~b}$ & KKM 22 & $2.38 \mathrm{~b}$ \\
\hline & & KW 165 & $2.39 \mathrm{a}$ \\
\hline
\end{tabular}


stomata) was affected by distance between trees and shade, which means that solar radiation affects diffusive resistance stomata or stomatal conductance. The transpiration values of perrenial crop varied from 2.0 to $17.0 \mu \mathrm{g} . \mathrm{cm}^{-1}{ }^{-} \mathrm{s}^{-1}$ and the stomatal resistance from 2.5 to $30.0 \mathrm{s.cm}^{-1}$ (Sena et al., 2007).

Transpiration rates initially increased and declined which were caused by differences in stomatal reaction to vapour pressure deficit (VPD). This was also observed by Hernandez et al. (1989) who reported that rapid closure of stomata as VPD was increased reduced transpiration in coffee, cacao and tea. The content of $\mathrm{CO}_{2}$ increased photosynthesis rate and decreased stomata resistance diffusion. The characteristic of stomata influenced $\mathrm{CO}_{2}$ fixation in the leaf mesophyll (Wong et al., 1979).

Based on this research, stomatal index was affected by shade tree species and clones. The higher the stomatal index, the higher the number of stomata. However, it is also influenced by number of existing epidermis. Meanwhile, the stomatal index of Sulawesi 01 was $20.6 \%$, which was significantly different than other clones.
Stomatal index derived from the ratio of the number of stomata and epidermis. The stomata index of Leaucena sp., Cassia surattensis, Tectona grandis were 19.8\%, $18.9 \%$ and $18.0 \%$, respectively. However, it was seemed that Leucaena sp. shade provided the highest stomata index than Tectona grandis. It shows that the increasing of shading percentage will be followed by the increasing of stomatal index (Regazoni, 2014; Wahyudi et al., 2014).

Interaction were not significantly different in chlorophyll parameters. Meanwhile, clones and shade tree species provided significantly different in chlorophyll, Leucaena sp. shading provides the highest chlorophyll content $\left(397.5 \mathrm{~mol} \mathrm{~m}^{-2}\right)$. Sulawesi 01 clones had the highest chlorophyll value (416.8 $\mathrm{mol} \mathrm{m}^{-2}$ ).

The production could be shown in the number pods per tree in two semesters. In semester 1, production was lower than semester 2 due to heavy rain that caused flower falling. Number of pods per tree on Sulawesi 01 was higher (16.1 pods/tree). However, KW 165 had high cherelle wilt level that caused low number mature pods (Figure 1).

Table 4. Effects of shade tree species and cocoa clones on stomatal index

\begin{tabular}{lccc}
\hline Shade trees & Stomatal index, \% & Clones & Stomatal index, \% \\
\hline Leucaena sp. & $19.8 \mathrm{a}$ & Sulawesi 01 & $20.6 \mathrm{a}$ \\
Cassia surattensis & $18.9 \mathrm{a}$ & Sulawesi 02 & $19.1 \mathrm{~b}$ \\
Tectona grandis & $18.0 \mathrm{~b}$ & KKM 22 & $17.7 \mathrm{bc}$ \\
& & KW 165 & $18.1 \mathrm{c}$ \\
\hline Note: number within the same column follow by the same letter are not significantly different at 5\% level according to
\end{tabular}

Table 5. Effects of shade tree species and cocoa clones on chlorophyll content

\begin{tabular}{lccc}
\hline Shade trees & Chlorophyll, $\mu \mathrm{mol} \mathrm{m}{ }^{-2}$ & Clones & Chlorophyll, $\mu$ mol m ${ }^{-2}$ \\
\hline Leucaena sp. & $397.52 \mathrm{a}$ & Sulawesi 01 & $416.81 \mathrm{a}$ \\
Cassia surattensis & $347.03 \mathrm{~b}$ & Sulawesi 02 & $335.36 \mathrm{~b}$ \\
Tectona grandis & $360.41 \mathrm{ab}$ & KKM 22 & $382.47 \mathrm{ab}$ \\
& & KW 165 & $338.64 \mathrm{~b}$ \\
\hline Note: number within the same column follow by the same letter are not significantly different at 5\% level according to
\end{tabular}


According to the number of beans per pods, pod length, and pod girth showed there were no differences. Meanwhile, in the Leucaena sp. shading, pod girth was larger that indicated pod quality was better. In addition, pod husk weight under Leucaena sp. was smaller than Cassia surattensis and Tectona grandis. Assimilate was directed to form bean quality that can be shown in bean count (Figure 4).
Bean count means number of dry beans (7-8\%) per a hundred gram of dry bean. The smaller the bean count value, the more filled out that bean. Figure 4 shows that bean count under Leucaena sp. shades and Tectona grandis shades was lower than under Cassia surattensis shades. Sulawesi 01 clones under Leucaena shades was lower than other clones which ammounted to 93.4 dry beans $/ 100 \mathrm{~g}$ dry beans.

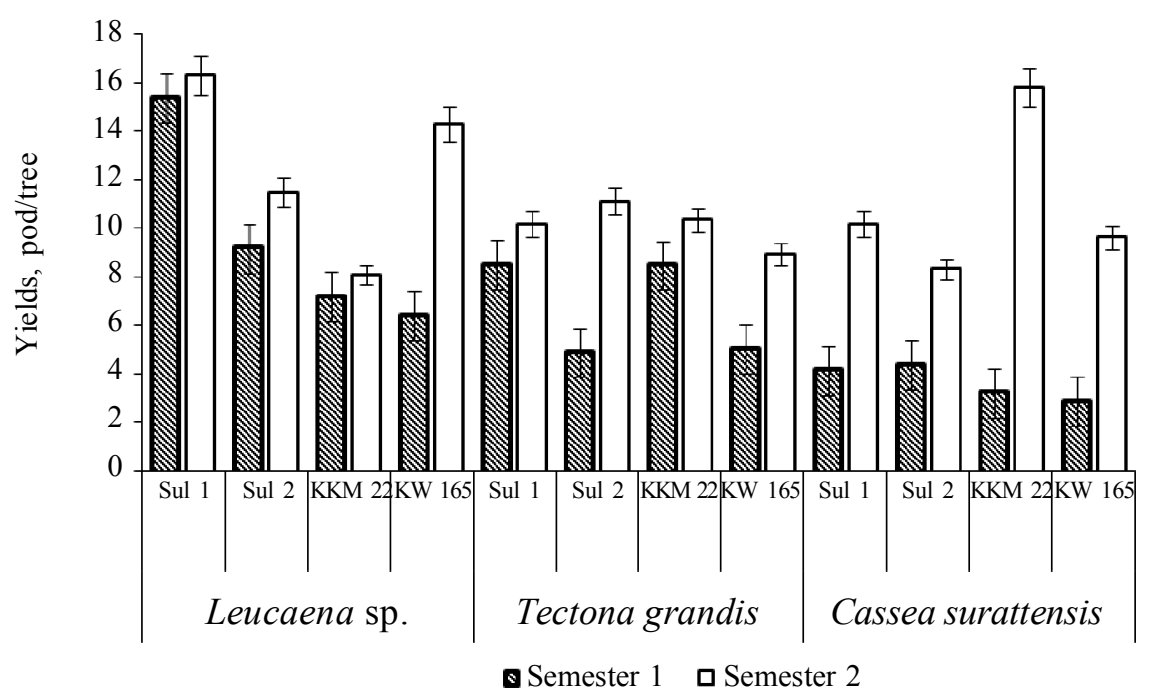

Figure 1. The number of pod per tree in Semester 1 and Semester 2 (Means \pm standard deviation)

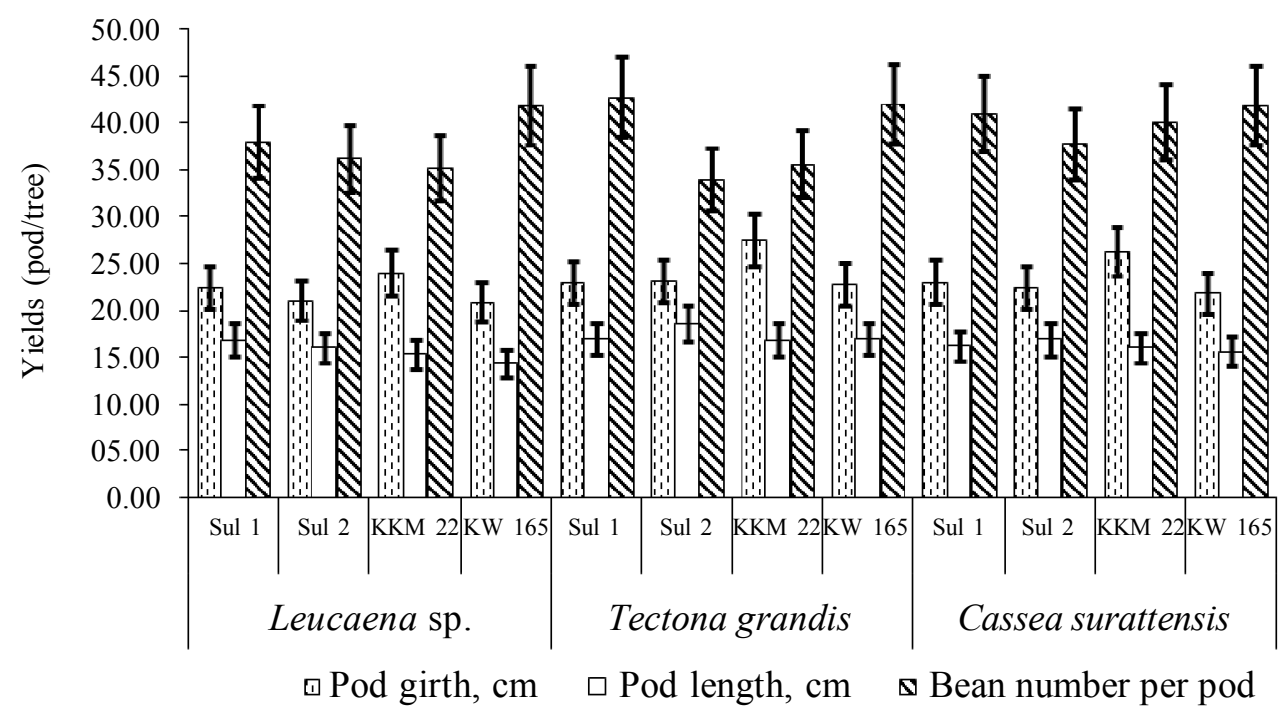

Figure 2. Pod girth, pod length, and the number of bean per pod (Means \pm standard deviation) 
Mayolie \& Gitau (2012) suggested that coffee and cocoa flowering is controlled by the amount of light reaching the coffee and cocoa trees, with more sunlight resulting in more flowers (Beer et al.,1998) possibly because more nodes are formed per branch or more flower buds exist at each node of coffee trees. Leucaena sp. is a nitrogen-fixing plant that may supply $254 \mathrm{~kg} \mathrm{~N} \mathrm{ha}^{-1} \mathrm{yr}^{-1}$ to crops in an alley cropping system (Pandey et al., 2006).

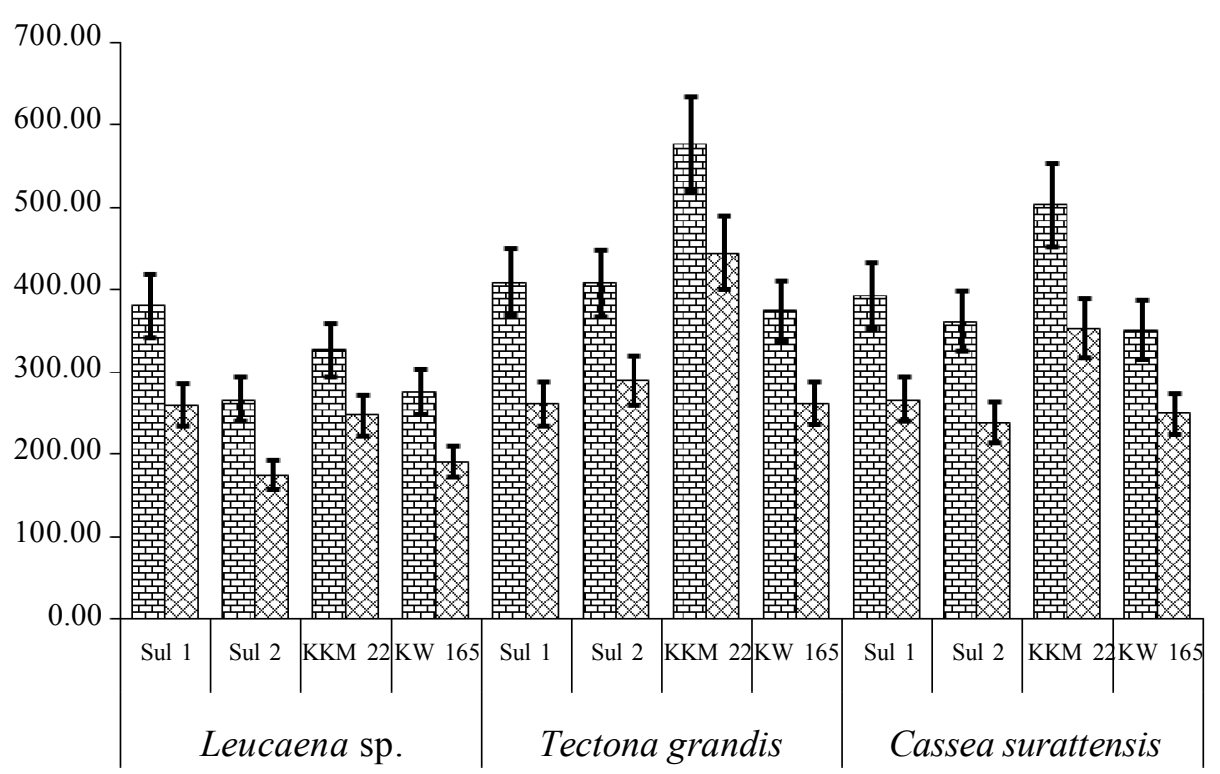

口Pod weight, $\mathrm{g} \otimes$ Pod husk, $\mathrm{g}$

Figure 3. Pod and husk weight (Means \pm standard deviation)

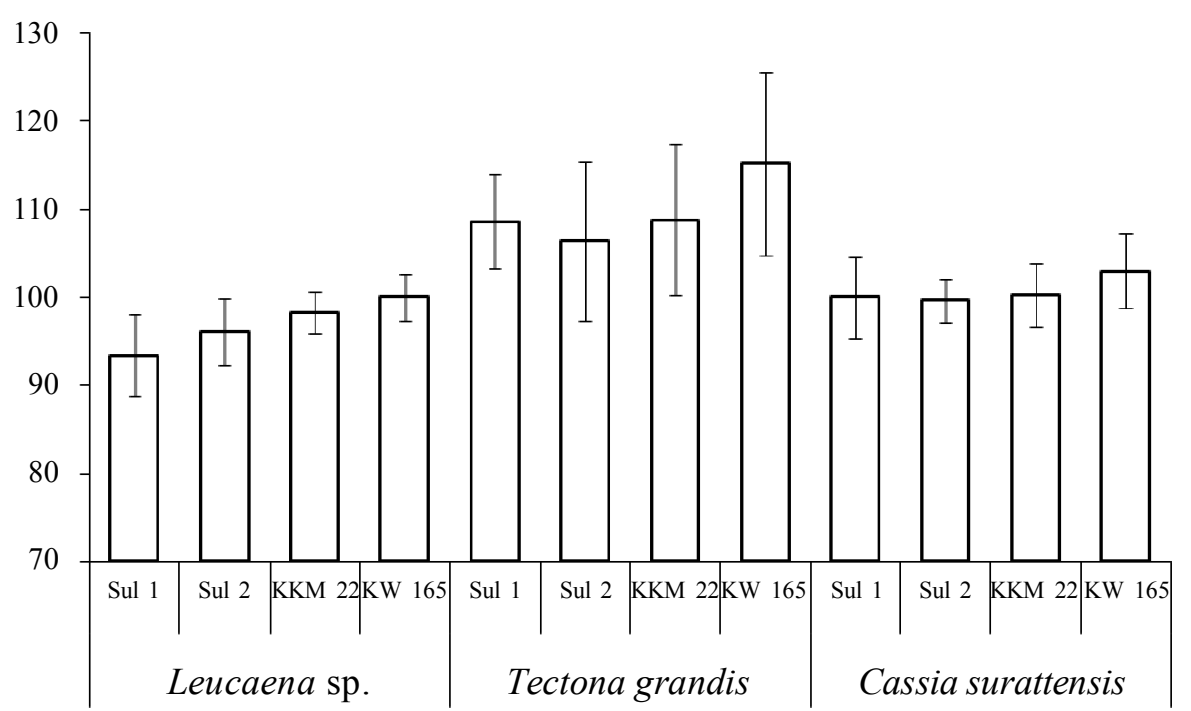

Figure 4. Bean count of $100 \mathrm{~g}$ dry beans (Means \pm standard deviation) 
Bean formation was affected by optimum physiological conditions. Based on this study, chlorophyll has an effect to increase the production that was shown by positive correlation coefficient $\left(\mathrm{R}^{2}=0.47\right)$. Chlorophyll may increase light absorbing surfaces as to increase the photosynthetic efficiency. The increasing of chlorophyll will be followed by the increasing of production. The high content of chlorophyll total will have high potential of biomass production (Suharja \& Sutarno, 2009; Daymond, 2011). In addition, transpiration has shown positive correlation coefficient $\left(\mathrm{R}^{2}=0.40\right)$.
Transpiration provides several advantages for plants by accelerating the rate of nutrient transport in the xylem vessels, keeping plant cells turgidity to remain in optimum condition and maintaining the stability of leaf temperature. The study of Novak \& van Genutchen (2008) revealed that yield and biomass in corn increased followed by increasing the transpiration. In addition, transpiration was highly correlated with total biomass of sorghum $\left(\mathrm{R}^{2}=0.82\right)$ (Vades et al., 2011), which was similar to that found recently by Xin et al. (2009).
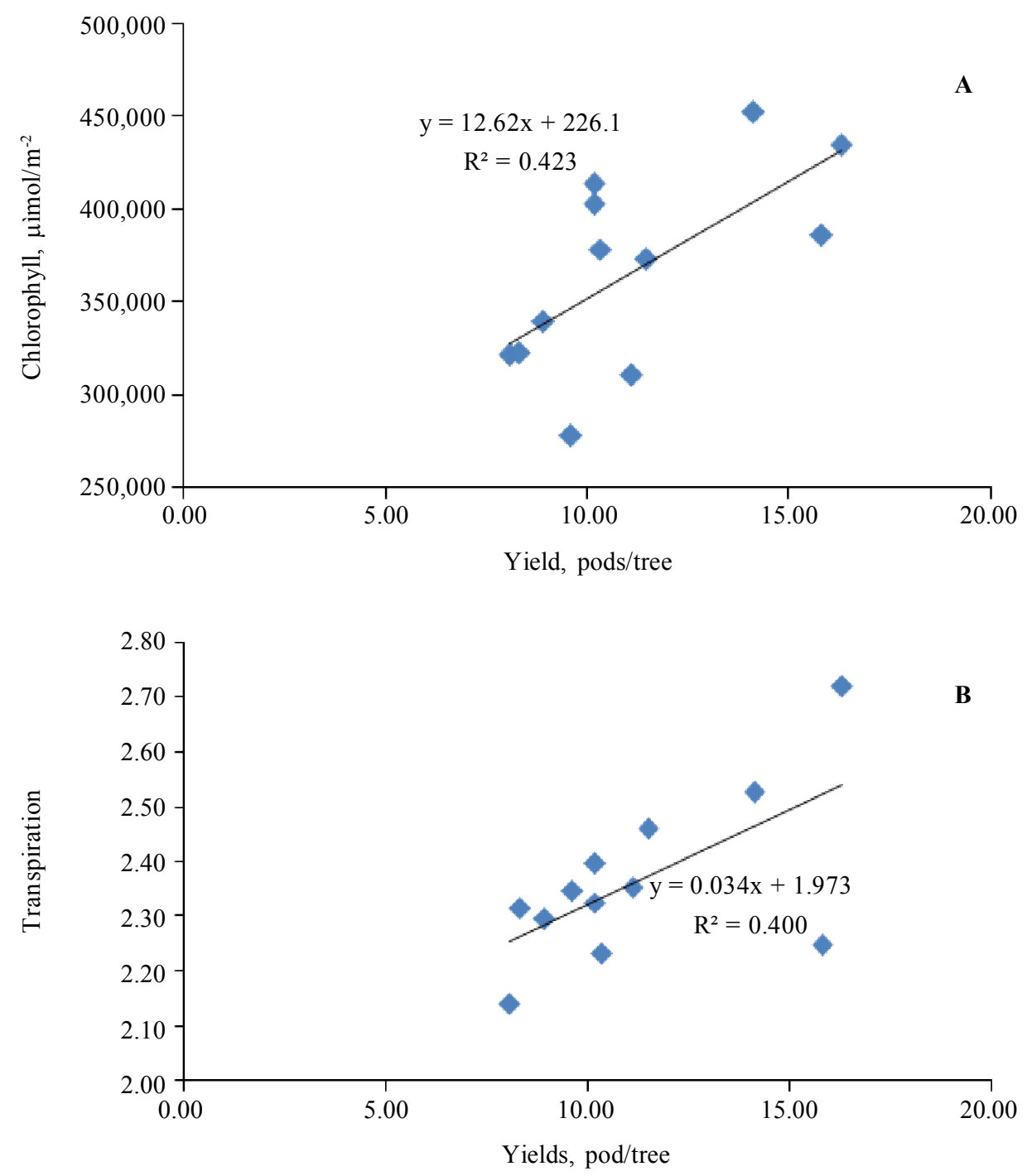

Figure 5. Relationship between number of pods per tree and chlorophyll content (A) and transpiration (B) 


\section{CONCLUSION}

Shade tree species affects stomatal conductance characters including transpiration, stomatal diffusion resistance and stomatal index, and chlorophyll content on some cocoa clones. Leucaena sp. is the best shade that provided optimum physiological conditions. Transpiration and photosynthesis have a positive correlation coefficient to production, which increased transpiration and chlorophyll, the production also increased. In this case maximum yield was obtained on Sulawesi 01 clone in Leucaena sp. shade.

\section{REFERENCES}

Abdoellah, S. \& Soedarsono (1996). Penaung dan pemangkasan kakao, suatu tinjauan dari aspek iklim mikro dan kesuburan tanah. Warta Pusat Penelitian Kopi dan Kakao, 12, 153-160.

Beer, J.R.; Muschler; D. Kass \& E. Sommariba (1998). Shade management in coffee and cacao plantations. Agroforestry Systems. 38, 139-164.

Cannell, M.G.R. (1985). Physiology of coffee crop. p. 108-134. In: M.N. Clifford \& K.C. Wilson (Eds.), Coffee, Botany, Biochemistry and Production of Beans and Beverages. CroomHelm, London.

Daymond, A.J.; P.J. Tricker \& P. Hadley (2011). Genotypic variation in photosynthesis in cacao is correlated with stomatal conductance and leaf nitrogen. Biologia Plantarum, 55, 99-104.

DaMatta, F.M.; C.P. Ronchi; M. Maestri \& R.S. Barros (2007). Ecophysiology of coffee growth and production. Brazilian Journal of Plant Physiology. 19, 485-510.

Ditjenbun (2011). Statistik Perkebunan Indonesia 2010-2012. Kakao. Direktorat Jenderal Perkebunan, Kementerian Pertanian. Jakarta, Indonesia.
Hernandez, A.D.P.; J.H.Cock \& M.A. El-sharkawy (1989). The responses of leaf gas exchange and stomatal conductance to air humidity in shade-grown coffee, tea, and cacao plants as compared with sunflower. Brasilian Fisiology Vegetale, 1, 155-161.

Lakitan, B. (2013). Dasar-Dasar Fisiologi Tumbuhan. Rajawali Press, Jakarta.

Markwell, J.; J.C. Osterman \& J.L. Mitchell (1995). Callibration of the Minolta SPAD-502 chlorophyll meter. Photosynthesis Research, 46, 467-472.

Mayoli, R.N. \& K.M. Gitau (2012). The effects of shade trees on physiology of Arabica coffee. African Journal of Horticultural Sciences, 6, 35-42.

Muschle, R.G. (2001). Shade improves coffee quality in a sub-optimal coffee-zone of Costa Rica. Agroforestry Systems. 51, 131-139.

Novak, V.\& M.Th. van Genuchten (2008). Using the transpiration regime to estimate biomass production. Soil Science, 173, 401-407.

Pandey, C.B.; D.K. Sharma \& S.S. Bargali (2006). Decomposition and nitrogen release from Leucaena leucocephala in central India. Tropical Ecology, 47, 149-151.

Prawoto, A.A. (2012). Impact of teak (Tectonagrandis Linn.) thinning out and peacock plume [Paraserianthes falcataria L. (I. Nielsen)] harvesting on mineral cycle, pod rot incidence, changing of cocoa yield, and land productivity in Indonesia. Journal of Agricultural Science and Technology, A 2. 438-448.

Prawoto, A.A. (2014). Pattern of cocoa flusing, cherelle wild and accuracy of yield forecasting of some cocoa clones. Pelita Perkebunan, 30, 100-114.

Prawoto, A.A. (2015). Pangkasan tanaman kakao. p. 205-226. In: Sejarah, Botani, Proses Produksi, Pengolahan dan Perdagangan. (T. Wahyudi, Pujiyanto 
\& Misnawi, Eds.). Gadjah Mada University Press, Yogyakarta.

Regazzoni, O.; Y. Sugito; A. Suryanto \& A.A. Prawoto (2014). Karakteristik fisiologi klon-klon kakao (Theobroma cacao L.) di bawah tiga spesies tanaman penaung. Pelita Perkebunan, 30, 23-34.

Salisbury, F. \& C.W. Ross (1995). Fisiologi Tumbuhan, Jilid 2. ITB Press, Bandung.

Sena, J.O.A.; H.A. Zai \& P.R.C. Castro (2007). Transpiration and stomatal resistance variations of perennial tropical crops under soil water availability conditions and water deficit. Brazillian Archives of Biology and Technology, 50, 51-67.

Suharja \& Sutarno (2009). Biomass, chlorophyll and nitrogen content of leaves of two chili pepper varieties (Capsicum annum) in different fertilization treatments. Bioscience, 1, 9-16.
Susilo, A.W. (2015). Bahan tanam kakao. p. 79-113. In: Kakao: Sejarah, Botani, Proses Produksi, Pengolahan dan Perdagangan. (T. Wahyudi, Pujiyanto \& Misnawi, Eds.). Gadjah Mada University Press, Jogjakarta.

Vadez, V.; L. Krishnamurthy; C.T. Hash; H.D. Upadhyaya \& A.K. Borrell (2011). Yield, transpiration efficiency, and water-use variations and their interrelationships in the sorghum reference collection. Crop \& Pasture Science, $62,645-655$.

Wong, S.C.; R. Cowan \& G.D. Farquhar (1979). Stomata conductance correlates with photosynthetic capacity. Nature, 282, $424-426$.

Xin, Z.; R. Aiken \& J.J. Burke (2009). Genetic diversity of transpiration efficiency in sorghum. Field Crops Research, 111, 74-80. 